The patient remains in good health and suffers no further inconvenience from his urinary organs than having occasionally to pass a full-sized bougie for himself. I frequently meet him.

CASE 2.-This patient, aged forty-five years, had a tough contractile stricture which had resisted dilatation and was complicated with several urinary fistula of two years' standing. I operated upon him in 1892. He was treated in the same way as the preceding patient and in addition the various fistulæ were opened up and scraped. The result was equally satisfactory and is so far permanent.

Perineal section carried out on these lines has been found to present many advantages. In the first place it is easier to effect a division of the hard and condensed tissues of the perineum, such as generally surround strictures of this kind, upon a fairly large staff than apon a small one or even upon the shouldered staff which Syme used for marking the commencement of the contracted portion of the canal. The freedom or otherwise with which the large-sized instruments move in the canal is sufficient to determine the necessity for proceeding at once with the external section, as well as the precise locality and degree of the contraction which remains. It may seem at first sight in combining these two operations that the magnitude of an ordinary perineal section is in creased. This, however, is not the case, as the division of more or less of the obstruction from within the canal has not infrequently proved sufficient to completely clear the urethra, whilst it invariably tends to limit considerably the extent of any external section which may still be required. Further, it mast be remembered that there is no kind of wound involving the deep aretbra which heals so kindly or is so free from those constitutional symptoms which occasionally follow operations on this canal than tbat where a temporary drain is established for the urine. Again, this point is importantly supported by the results following ruptare of the deep urethra from external violence. Cases of this kind where a perineal section is performed and a temporary drain established compare most favourably, both immediately and remotely, with those where the treatment consists in the retention of a catheter, when this can be passed, the points of distinction being in the former class of cases the absence of septic symptoms of a serious nature and the more favourable character of the scar which results. There is no worse kind of stricture to manage than that following an extensive rupture of the deep' urethra and its treatment by what may be described as the closed method. It is on grounds such as these that I believe the combined operation proves of much benefit in the treatment of some of the most serious and complicated forms of urethral stricture.

Before concluding these remarks I will briefly refer to a class of strictures which I have only incidentally noticed. This is the structurally impassable stricture-impassable alike to instruments and urine and associated invariably with an extraneous route for the urine, probably through the perineum. The latter condition is the result either of nature's effort to provide escape for the urine by abscess and fistula or of the surgeon's, more promptly and directly, by incision. In endeavouring to restore a urethra of this kind and to close a well-worn fistula the surgeon will fully recognise the mechanical and physiological difficalties before him not only in reproducing a portion of the canal which to all intents and purposes is obliterated, but in subsequently fitting it to take up the fanctions connected with the process of natural, or even aided, micturition. It requires no great amount of surgical ingenuity to establish the continuity of the urethra so far as instrumentation is concerned, but to secure a reasonable degree of control or influence over the restored portion of the canal is by no means certain. On the other hand, experience and trial have not infrequently shown that a good urinary fistula has proved an excellent substitute for a bad urethra.

Lower Berkeley-street, $W$.

Torguay Natural History Society. - The report presented at the annual meein $x$ of this society showed that there were 198 members and associates. A special vote of thanks was awarded to Mr. C. H. Wade, M.A. Oxon., M.R.C.S Eng., L.R C.P. L ind, for the large amount of time and trouble he bat devoted to the society.

\section{A CASE OF RECURRENT CANCER OF THE BREAST TREATED BY OÖPHOREC- TOMY AND THYROID EXTRACT.}

\author{
BX G. ERNEST H RRAN. M.B., F.R C.P. LOND.y \\ T.R.C.S. ENG.,
}

SENIOR OBSTETRIC PHYSICIAN TO 'IHE LONDON HOSPITAL, ETC.

A PATIENT, aged forty years, consulted me as to a lump in the left breast. The patient's weight was then $10 \mathrm{st} .3 \mathrm{lb}$. She had had two children, the last thirteen years ago. Menstruation was regular. The characters of the lump led to the opinion that it was cancer, and the patient was advised to see a surgeon. The result of this advice was that in October, 1890, Mr. Treves removed the left breast. Tho whole mamma was removed, but as no glands were dis. covered in the axilla the axillary space was not evacuated. The breast after removal was cut into, and the tumour was found to present all the characters of cancer so well marked that it was not thought necessary to complete the diagnosis by microscopical examination. The patient recovered well from the operation. In July, 1893, her weight was 11 st. 2 lb. In November, 1895, it was 11 st. $1 \mathrm{lb}$. In the beginning of 1896 she began to lose flesh. In May, 1896, she weighed 9 st. $12 \mathrm{lb}$., and in July $8 \mathrm{st} .13 \mathrm{lb}$. After this she gained a little, reaching $9 \mathrm{st} .6 \mathrm{lb}$. in October. Towards the end of December she noticed a lump in the armpit, which induced her to again come for examination. As a result of this on Jan. 4th, 1897, Mr. Treves cut down first upon a lump just above the clavicle and then upon the lump in the armpit. The lump above the clavicle was found to be an indurated fixed gland in such close relation to the subclavian vein that its removal was unadvisable. When the axilla was exposed, a mass of new growth was found quite surrounding the axillary vessels. There were also nodules in the pectoralis major. The new growth was so extensive that the com. plete removal of the axillary growth conld have been effected only by amputation of the upper extremity, and if this had been done the supra-clavicular nodule would have remained. The incisions were therefore closed without any attempt to remove the recurrent growths. The wounds healed well.

As there was no prospect of cure by any other treatment the case in which Dr. Beatson observed disappearance of recurrent cancer of the breast after oöphorectomy and the administration of thyroid extract was put before the patient and her husband, and after consideration they decided to accept this chance of cure. Menstruation had been irregular for about three years, but had not ceased. She had last menstruated on Jan. 3rd, 1897. On March 2nd, 1897, I removed both ovaries. They presented small cysts but were otherwise healthy. As soon as the vomiting caused by the anæsthetic had passed off the patient began to take thyroid extract; at first the glycerine extract made by Allen and Hanburys, then either tabella from Allen and Hanburys or tabloids from Burroughs, Wellcome and Co. She has taken this ever since in as fall doses as she could, varying from $10 \mathrm{gr}$. to $15 \mathrm{gr}$. daily. She has occasionally had to diminish the dose on account of dyspeptic symptoms-vomiting and epigastric pain-thought to be produced by it. On Sept. 27th, 1897, she came up for examination. Mr. Treves and I examined the parts. The supra-clavicular nodule was no longer to be felt. The axillary artery could be felt pulsating, apparently quite free from growth around it. The patient's weight, which on March 27th, 1897, was 8 st. $4 \frac{1}{2} \mathrm{lb}$, is now (May, 1898) 8 st. $10 \frac{1}{2} \mathrm{lb}$. On May $5 \mathrm{th}, 1898$, the patient was eeen by Dr. G. C. Tayler of Trowbridge, who reported as follows: "I examined the operation scars this day and find that they are pale-almost the colour of the neighbouring skinsoft, no adhesion to the subjacent parts, and no deposits of any kind in the surrounding tiesues."

In this case, as in one published by Dr. Beatson, recurrent cancerous growths atrophied after removal of the ovaries and the administration of thyroid extract. The length of time since the operation during which the patient has remained well-fourteen months-is enough to justify the assertion that the course of the disease has teer modified by the treatment. 
Since the pablication of Dr. Beatson's case Mr. Stanley Boyd and Mr. Watson Cheyne have reported cases of oöphorectomy for mammary cancer, but it is not stated in their reports that thyroid extract was given. Thyroid extract has very powerfal effects upon the body, and I think Dr. Beatson's practice cannot be said to have been followed if thyroid extract has not been given. Cases treated by oöphorectomy without thyroid extract do not justify a conclusion as to the uselessness of oöphorectomy plus tbyroid extract. My reason for combining oöphorectomy with thyroid extract was simply that Dr. Beatson's successful case was treated in that way. The explanation of the benefit which seems to me the probable one is that based on the protozoon theory of cancer-that the withdrawal of the ovarian secretion, coupled with the presence of an excess of the thyroid secretion, makes the tissces of some persons a less fir food for the cancer protozoon.

I have since treated some cases of uterine and vaginal cancer by oöphorectomy and thyroid extract, bat the results are not yat complete enough for publication.

Harley-street, W.

\section{THE LOSS OF SEXUAL POWER IN TABES DORSALIS.}

BY R. CUNYNGHAM BROWN, M.D. DURH.,

CLINICAL ASSISTANT TO THE NATIONAT HOSPITAL FOR THE PARALYSED AND EPILEPTIC, QUEEN-SQUARE; IAATE JUNIOR HOUSE SURGEON AND SENIOB ASSISTANT HOUSE SURGEON, HODDERSFIFID INTIRMARY.

Loss of sexual power is one of the most constant disturbances of function encountered in tabes, being present in at least 70 per cent. of cases of over two years' duration. Leimbach ${ }^{1}$ found it present in 5825 per cent. of all cases of whatever duration, and in 15.54 per cent. it was one of the earliest symptoms of the disease. Before investigating, however, this distarbance of function it may be well to glance at the normal mechanism. Erection is a complex process largely reflex in nature, having for its afferent limb fibres passing from the glans penis and penis to the upper sacral and lower lumbar cord and for its efferent limb fibres passing from the cord to branches supplying the pudic and dorsal arteries of the penis and the transversus peringi and balbo-cavernosus muscles. Erection therefore depends partly on the presence of afferent stimuli ascending from the penis, but may also be initiated or inhibited by cerebral impulses. Ejaculation is an act more dependent than erection on the presence of afferent stimuli. The afferent impulses in this case also come mainly from the glans penis. The efferent impulses are spread over a larger area than in the case of erection, effecting peristaltic contraction of the muscles of the epididymis, vas deferens, and prostate, and later rhythmic contractions of the levator ani, sphincter ani, constrictor urethræ, \&c.

Tabes being mainly, if not entirely, a disease of the mechanism subserving the production and transmission of afferent impalses, it is to be expected that the loss of sexual power in tabes should be found to be due to the diminution or loss of those afferent impalses concerned in the act. The larger contention, that tabes is entirely a disease of the mechanism subserving the production and transmission of afferent stimuli, is outside the range of this paper, but in this connexion Dr. Warrington's paper $^{2}$ on the effect of section of the posterior roots on the cells of the anterior horn and that of $\mathrm{Dr}$. Schaffer ${ }^{3}$ on the changes in the cells of the anterior horn in tabes are of great value. Clinical experience, however, shows clearly the part which loss of afferent stimuli plays in the production of loss of sexual power. of 12 cases of tabes taken at random 2 were women and not examined from this point of view. Of the remaining 10, 8 had suffered from tabes for a period of two years or more, and in these loss of sexual power was present in 6 . None of them were old men, only one being ove: forty years of age. Now in every one of these 6 cases in which there was loss of sexual power there was absolnte analgesia of the glans and comparative or absolute analgesia

1 Leimbach : Deutsche Zeitschrift für Nervenheilkunde, 1895.

2 Warrington: A paper read before the Liverpool Medical Institution on April 21st, 1898 . THE LaNCET, April 30th, 1898

3 Sohaffer: Monatsschrift für Psychiatrie und Neurologie, Berlin, 1888, Band ij., S. 61-98. of the rest of the penis. 4 of these had in addition comparative loss of tactile sensibility in the penis and glans, but in the other 2 tactile sensibility was normal. Further, in the 4 cases in which there was no loss of sexual power there was no affection of sensibility of the penis or glans. These figures are very significant and indicate very clearly that the alteration in sexual power is closely related to the diminution or loss of afferent impulses from the skin and possibly deeper structures of the glans and penis.

The loss of sexual power is gradual in onset and exists in proportion to the amount of analgesia of the glans. In the majority of cases examined, also, the condition might be described as belonging to one of two stages: (1) that of loss or diminution of voluntary sexual power with persistence of involuntary erection and emission; and (2) loss of both voluntary sexual power and involuntary emission. In the first stage analgesia of the glans alone or accompanied by diminished tactile sensibility is present, but the testicles are not atrophied and testicular sensation is present. In the second stage there are in addition atrophy of the testicles and loss of testicular sensation. The first stage passes gradually into the second, but a considerable time may elapse before complete loss of gexual power is established. In one case, three years after the loss of voluntary power, erection and emissions of purely cerebral origin occurred with regalar frequency. This persistence of emission of cerebral origin shows that the efferent paths may remain capable of function long after the reflex process is impossible and indicates the afferent nature of the lesion. As to the site of the morbid processes at work it is impossible to speak with certainty at this stage. Gumpertz, ${ }^{4}$ however, has demonstrated changes very early in tabes in the peripheral nerve structures, and it is, at any rate, possible that this, as well as other symptoms of tabes, is due to disease commencing not in the posterior spinal ganglia or in the posterior root at its junction with the cord, but in the extremely peripheral nerve structures subserving the production and transmission of afferent impulses.

Chancery: lane, W.C.

\section{VITALITY :}

\section{AN APPEAL, AN APOLOGY, AND A CHALLENGE ADDRESSED TO BROTHER PRACTITIONERS.$$
\mathrm{BY}
$$

\section{LIONEL S. BEALE.}

(Continued from page 1050.)

$\triangle M O N G$ the untenable propositions enumerated not the least extravagant is that in which the growth of living things is classed with the process of accretion or aggregation in the non-living world. Only watch the gradual living growth as seen by all in the little child. Can the faintest analogy be pointed out between this vital growth and any inorganic process whatever? Think of the increase of the several complex tissues, for example, in the arm or in a finger. As the member grows in length, do not the nerve plexuses distributed to the peripheral parts become separated by a gradually increasing distance from the nerve centres, and does not this change occur not only without interraption but at the same time that steady improvement in nerve action is taking place? Do not new tissue formations, new growth, and new nerve action all actively proceed and simultaneously? How, then, can such phenomena be cansed, directed, and regulated by physics or swayed by chemistry?

If we study but a small particle of the growing tissnes in properly prepared microscopical specimens we shall find millions of minute bioplasts among the tissues formed daring growth-the vital phenomena and tissue formation and action proceeding with great regularity during the whole period; not only so, but evidence of anticipation of a fature condition, of preparation for further growth and arrangement of tissue. Thus the complete development and action of the several tissues and their continued and healtby action are provided for during youth, adolescence, maturity, old age, decrepitude, ap to death-one stage so gradually passing 4 Gumpertz': Berliner Medicinische Wochenschrift, 1898, Band xxxv." p. 62 . 